\title{
Relative Contributions of Surface Roughness and Crystalline Structure to the Biocompatibility of Titanium Nitride and Titanium Oxide Coatings Deposited by PVD and TPS Coatings
}

\author{
Sinem Yeniyol, ${ }^{1}$ Nilüfer Bölükbaşı, ${ }^{1}$ Ayhan Bilir, ${ }^{2}$ Ali Fuat Çakır, ${ }^{3}$ \\ Mefail Yeniyol, ${ }^{4}$ and Tayfun Ozdemir ${ }^{1}$ \\ ${ }^{1}$ Department of Oral Implantology, Faculty of Dentistry, Istanbul University, Capa, P.O. Box 34093, Istanbul, Turkey \\ ${ }^{2}$ Department of Histology and Embryology, Faculty of Medicine, Istanbul University, Capa, P.O. Box 34390, Istanbul, Turkey \\ ${ }^{3}$ Department of Metallurgical and Materials Engineering, Faculty of Chemical and Metallurgical Engineering, \\ Istanbul Technical University, Maslak, P.O. Box 34469, Istanbul, Turkey \\ ${ }^{4}$ Department of Geological Engineering, Faculty of Engineering, Istanbul University, Avcilar, P.O. Box 34320, Istanbul, Turkey
}

Correspondence should be addressed to Sinem Yeniyol; yeniyols@istanbul.edu.tr

Received 25 March 2013; Accepted 19 May 2013

Academic Editors: B. F. Ali, K. Y. Choi, J. Langer, L. G. Lopes, and J. Svorec

Copyright (C) 2013 Sinem Yeniyol et al. This is an open access article distributed under the Creative Commons Attribution License, which permits unrestricted use, distribution, and reproduction in any medium, provided the original work is properly cited.

\begin{abstract}
This study was conducted to characterize titanium (Ti) metal surfaces modified by polishing, coating with titanium nitride, coating with titanium oxide, sandblasting with alumina $\left(\mathrm{Al}_{2} \mathrm{O}_{3}\right)$ particles and coating with titanium oxide, coating with titanium plasma spray (TPS); and to evaluate the effect of surface roughness and crystalline structure on adhesion of human fetal osteoblast cells (CRL-11372) in vitro after 24 hours. Surface topography and roughness were examined by scanning electron microscopy (SEM) and a noncontacting optical profilometer, respectively. The crystalline structures of the coatings were characterized by X-ray diffraction (XRD). CRL-11372 cells were incubated at these surfaces for $24 \mathrm{~h}$ and were evaluated for their mean total cell counts and cell viabilities. Cell morphologies were examined qualitatively by SEM images. Glass discs served as control group (CG) for the cell culture experiments. Surfaces at the Group TPS had the highest $R_{a}$ and $R_{z}$ values. Highest mean total cell counts were found for the CG. SC (sandblasted and $\mathrm{TiO}_{2}$ coated) surfaces had shown sparsely oriented CRL-11372 cells while other surfaces and CG showed confluency. Surfaces displayed diverse crystalline structures. Crystalline structures led to different cellular adhesion responses among the groups regardless of the surface roughness values.
\end{abstract}

\section{Introduction}

Studies on implant surfaces have evaluated topographical modification to optimize cellular responses at the boneimplant interfaces. It is widely acknowledged that topography and surface chemistry improvements of the materials potentiate dental implant surfaces' cytocompatibility [1-3].

Major determinants of the bone-implant interface structure are the initial adhesion, spreading, proliferation, and differentiation of osteoblast cells on the implant surfaces and these processes are proven to lead to faster and more extensive implant integration and long-term stability [4]. Cell adhesion to the implant surfaces is the critical starting point of the biological functions at the interface influencing the cellular responses of the organism [5]. The biocompatibility of biomaterials is related to the behavior of the contacting cells, in particular cell adhesion. Cell adhesion affects cell growth, proliferation, and differentiation. Adhesion in the biomaterial domain involves temporary events such as physicochemical linkages between cells and materials involving van der Waals and electrostatic forces. The adhesion phase may also involve biological molecules such as extracellular matrix proteins, cell membrane proteins, and cytoskeleton proteins 
that interact together to induce signal transduction, thus promoting the action of transcription factors and consequently regulating gene expression. In the initial phase of cellmaterial interactions, the quality of attachment, adhesion, and spreading influences the capacity of the cell to proliferate and differentiate in contact with the biomaterial [4]. One way to improve the success of Ti-based materials is to alter their surface properties since initial cell adhesion with an implanted material occurs at this stage [6]. Mechanism of cellular adhesion together with the quality of the connection between the adherent growing cells (e.g., osteoblast-like cells, fibroblasts, and endothelial cells) and the biomaterial can be influenced by the chemistry as well as the dimensions of the surface topography [7]. Dental implant surfaces are modified with a large range of surface roughness values from relatively smooth machined surfaces to those roughened by coatings, abrasion or blasting, or acid etching or by a combination of these techniques [8]. One of the challenges to further improve the biological capability of implants is to enhance their surface chemistry without altering the proven microfeatures [9]. With the development of the thin coating technology, recent studies have started to focus on creating unique thin coatings of $\mathrm{TiN}$ and $\mathrm{TiO}_{2}$ to control cellular functions [1012]. TiN has drawn attention due to its mechanical properties, such as hardness, corrosion resistance, shear strength $[8,13$, 14], and biological properties such as biocompatibility [15] and haemocompatibility [16-18]. The high hardness and low coefficient of friction of these coatings have been exploited for applications such as drills or cutting tools leading to increases in lifetime as excellent tribological coatings $[18,19]$. The use of TiN for dental prostheses [20], hip joint, and heart valve prostheses [21-23] had been reported, because of their desirable properties, such as relatively low modulus, good fatigue strength, formability, machinability, corrosion resistance, and biocompatibility.

Most of the studies entitled with $\mathrm{TiO}_{2}$ coatings usually included tissue attachment with titania-silica mixed oxide coatings and hydroxyapatite-titania composite coatings [2426]. Sol-gel derived titania coatings were found to facilitate direct soft tissue attachment. This was considered to result in improved biocompatibility, protein adsorption, and cell attachment enhancing the reactivity of the titanium surface [27]. Meretoja et al. [28] showed that the sol-gel-derived $\mathrm{TiO}_{2}$ coatings can facilitate the cell growth and attachment of human gingival fibroblasts on titanium in vitro. In a clinical study by Wennerberg et al. [29], it was stated that with the $\mathrm{TiO}_{2}$ surface modification, clinical benefits could be expected in early healing of soft tissue as well as increased adherence of soft tissue and reduced marginal bone resorption.

TiN and $\mathrm{TiO}_{2}$ had been shown to have substantial influence on the reduction of bacterial adherence and colonization $[30,31]$. In this way, applications around transmucosal parts of the implants were expected to avoid inflammation at the soft tissues. Applications of alternative surface preparation methods to modify and produce surface oxide on titanium have been previously investigated to regulate and enhance cell adhesion. Titanium implant surfaces coated with $\mathrm{TiO}_{2}$ using a Physical Vapor Deposition (PVD) process has been evaluated as carrier oxide coatings to enhance peri-implant osseointegration and gap bridging by the construction of an immobilized layer of rhBMP-2 [32].

PVD processes are used to apply thin coatings of TiN and $\mathrm{TiO}_{2}$, allowing the chemical composition and crystalline structure of the surface to change while preserving the microroughness of the implant surface [33]. These atomistic deposition processes in which materials are vaporized from a solid or liquid source in the form of atoms or molecules are transported in the form of a vapor or plasma in a vacuum or low pressure gaseous (or plasma) environment to the substrate, where they condense. PVD processes are employed to fabricate films with thicknesses ranging from a few nanometers to thousands of nanometers; however, they can also be used to form multilayer coatings, graded composition deposits, very thick deposits, and freestanding structures [34]. Ballo et al. [33] had claimed that early bone-promoting effect during the healing of implants with a thinner oxide and different nanotopography should be characterized to optimize the early phases of osseointegration.

Titanium plasma spray coating consists of interactions that include gas adsorption followed by chemical interaction and formation of an oxide layer and other bonds on the surface, dissolution as molten particles, and diffusion and mechanical mixing of the products. Some bioinert ceramics with excellent mechanical properties, such as $\mathrm{Al}_{2} \mathrm{O}_{3}$, $\mathrm{ZrO}_{2}$, and $\mathrm{TiO}_{2}$, can be deposited onto titanium by plasma spraying [35]. Synthesis of TiN-Ti composite using reactive plasma spray technique has also been practiced by various researchers, where nitrogen has been used as reactive gas [36].

In this context, to further enhance the biological properties of featured titanium surfaces, the objective of this in vitro study was to test the hypothesis that (1) the surface crystalline structures of titanium surfaces can be controllably varied by coating with a layer of titanium nitride or titanium oxide, without altering the existing roughness features; and (2) the change in the surface crystalline structure affects the biological response of the CRL-11372 cells.

\section{Materials and Methods}

2.1. Materials. A total of 20 commercially pure Ti discs (grade 2, Friadent $\mathrm{GmbH}$, Mannheim, Germany) measuring $10 \mathrm{~mm}$ in diameter and $2 \mathrm{~mm}$ in thickness were grounded and polished up to a $1 \mu \mathrm{m}$ diamond abrasive suspension with metallurgical papers to obtain a mirror finish surface using Struers RotoSystem (Struers, Glasgow, England).

Five groups (each $n=4$ ) of surface-modified Ti discs were prepared and characterized as follows.

(1) Group P: polished Ti discs;

(2) Group TiN: TiN coated polished Ti discs (TiN coatings were deposited in $100 \% \mathrm{~N}_{2}$ environment using a pure Ti cathode via PVD);

(3) Group C: $\mathrm{TiO}_{2}$ coated polished Ti discs $\left(\mathrm{TiO}_{2}\right.$ coatings were deposited in $100 \% \mathrm{O}_{2}$ environment using a pure Ti cathode via PVD);

(4) Group SC: $\mathrm{TiO}_{2}$ coated sandblasted $\mathrm{Ti}$ discs $\left(\mathrm{Al}_{2} \mathrm{O}_{3}\right.$ particles of $800 \mu \mathrm{m}$ grain size under a pressure of 
6 bars were used for sandblasting; $\mathrm{TiO}_{2}$ coatings were deposited in $100 \% \mathrm{O}_{2}$ environment using a pure $\mathrm{Ti}$ cathode via PVD);

(5) Group TPS: TPS coated Ti discs (Friadent, GmbH, Mannheim, Germany).

2.2. Surface Characterization. The surface morphologies of the discs were characterized using a SEM (JSM5410, JEOL, Tokyo, Japan) at a $10 \mathrm{kV}$ acceleration voltage and $\times 1000$ magnification. The XRD analyses were carried out on surface treated samples using a Philips PW 3710 diffractometer, with $\mathrm{Cu}-\mathrm{K} \alpha$ radiation and a graphite monochromator, operated at $20 \mathrm{kV}$ and $10 \mathrm{~mA}$. The samples were measured from 20 to $80^{\circ} \theta$ with a step size of $0.01^{\circ} 2 \theta \mathrm{min}^{-1}$. Surface roughness was determined by a noncontacting optical profilometer (Perthometer S8P, Perthen-Mahr, Göttingen, Germany). Two heightdescriptive parameters as $R_{a}$ (the arithmetic average of the absolute deviation from the mean line over a sampling length) and $R_{z}$ (the arithmetic average of the five highest-profile peaks and the five lowest-profile valleys over the entire measurement trace) were used to quantify the surface roughness.

2.3. Cell Culture and Data Analysis. Human fetal osteoblast cells (CRL 11372, ATCC American Type Culture Collection, Manassas, VA, USA) were cultured in DMEM-F12 medium supplemented with penicillin (100 units/mL) and streptomycin $(100 \mu \mathrm{g} / \mathrm{mL})$, L-Glutamine $(2.5 \mathrm{mM})$, HEPES buffer $(15 \mathrm{mM})$, sodium pyruvate $(0.5 \mathrm{mM})$, sodium bicarbonate $(1.2 \mathrm{~g} / \mathrm{L}), \mathrm{G} 418$ sulphate $(0.3 \mathrm{mg} / \mathrm{mL})$, and $10 \%$ fetal calf serum. The cells were allowed to adhere on the substrates at $34^{\circ} \mathrm{C}$ in a humidified atmosphere of $5 \% \mathrm{CO}_{2}\left(\mathrm{CO}_{2}\right.$ Incubator MCO-17AI, Sanyo, Japan). Medium was changed every three days and cells were subcultured ( $0.25 \%$ trypsin). The cells were counted and the concentration was adjusted to $1 \times 10^{5}$ cells/mL with $100 \%$ viability. Sterile discs ( $25 \mathrm{kGy}$; gamma radiation) were placed in sterile six-well culture plates. On every sample, $50 \mu \mathrm{L}$ of a cell suspension was applied and the cells were allowed to attach for 60 minutes to the underlying substrate; afterwards $1 \mathrm{~mL}$ of culture medium was added into each well. Osteoblast cells grown on glass discs were used as Control Group (CG) for the cell culture assay. Cell adhesion on each surface at $24 \mathrm{~h}$ from plating was measured by counting the cells after trypsinization and cell viability was estimated by counting the number of cells which excluded Trypan blue solution (in 0.4\% PBS) (Gibco, Grand Island, NY, USA) in a hemocytometer.

2.4. Morphological Analysis. After the $24 \mathrm{~h}$ cell adhesion assay, the washed samples containing cell layers were fixed with $2.5 \%$ glutaraldehyde in $0.1 \mathrm{M}$ cacodylate buffer $(\mathrm{pH}$ 7.4) for $1 \mathrm{~h}$ at $4^{\circ} \mathrm{C}$. Cells were washed twice for $10 \mathrm{~min}$ with $0.1 \mathrm{M}$ sodium cacodylate buffer and postfixed in $1 \%$ osmium tetroxide for $1 \mathrm{~h}$ at $4^{\circ} \mathrm{C}$. Cells were dehydrated stepwise in graded acetone series and incubated in amyl acetate. The samples were critical-point dried, sputter coated with gold-palladium, and then evaluated in terms of their cell morphologies under SEM (JSM5200, JEOL, Tokyo, Japan) at various magnifications and accelerating voltages.
TABLE 1: Surface roughness assessment of the surfaces. $R_{a}=$ the arithmetic average of the absolute deviation from the mean line over a sampling length; $R_{z}=$ the arithmetic average of the five highest-profile peaks and the five lowest-profile valleys over the entire measurement trace. Means \pm SDs are shown.

\begin{tabular}{lcc}
\hline Group & $R_{z}(\mu \mathrm{m}) \pm \mathrm{SD}$ & $R_{a}(\mu \mathrm{m}) \pm \mathrm{SD}$ \\
\hline $\mathrm{P}$ & $1.32 \pm 0.36^{*}$ & $0.05 \pm 0.01^{\| 1}$ \\
TiN & $4.17 \pm 0.52^{\dagger}$ & $0.26 \pm 0.02^{\ddagger}$ \\
$\mathrm{C}$ & $4.06 \pm 0.52^{\dagger}$ & $0.31 \pm 0.02^{* *}$ \\
SC & $25.71 \pm 2.19^{\ddagger}$ & $4.22 \pm 0.50^{\dagger \dagger}$ \\
TPS & $38.97 \pm 3.81^{\S}$ & $5.77 \pm 0.64^{\S}$ \\
& $K W: 89.84$ & $K W: 93.19$ \\
& $P<0.0001$ & $P<0.0001$ \\
\hline
\end{tabular}

${ }^{*}$ Significant difference compared with Groups TiN, C, SC, and TPS (significant at $99.9 \%$ )

${ }^{\dagger}$ Significant difference compared with Groups P, SC, and TPS (significant at 99.9\%).

${ }^{\ddagger}$ Significant difference compared with Groups P, TiN, C, and TPS (significant at $99.9 \%)$.

${ }^{\S}$ Significant difference compared with Groups P, TiN, C, and SC (significant at $99.9 \%$ ).

"Significant difference compared with Groups C (significant at 95\%), SC, and TPS (significant at 99.9\%).

'Significant difference compared with Groups SC and TPS (significant at 99.9\%).

${ }^{* *}$ Significant difference compared with Groups P (significant at 95\%), SC, and TPS (significant at $99.9 \%$ ).

${ }^{\dagger \dagger}$ Significant difference compared with Groups P, TiN, C, and TPS (significant at $99.9 \%)$.

2.5. Statistical Analysis. All measurements were done four times and expressed in mean \pm standard deviations. The difference between the means for each group was analyzed by Kruskal-Wallis test followed by Post Hoc LSD test comparisons using SPSS 10.0 (SPSS Inc., Chicago, USA) program. Differences were considered significant at $P<0.05$.

\section{Results}

3.1. Surface Topographic Evaluation. SEM images of each modified surface are shown in Figures 1(a), 1(b), 1(c), 1(d), and $1(\mathrm{e})$. The quantitative surface roughness measurements are demonstrated at Table 1.

Coating with either TiN (Figure 1(b)) or $\mathrm{TiO}_{2}$ (Figure 1(c)) had qualitatively altered the surface character of the polished surfaces (Figure 1(a)) by scattered droplet formations onto them originating from the sudden cool down of the coating material upon impinging the surface during the PVD process. Deep valleys and high peaks of the Group SC (Figure 1(d)) were covered with droplets including the surface of $\mathrm{Al}_{2} \mathrm{O}_{3}$ particles impinged to the surface. The distinctive surface topography of the Group TPS could be distinguished by the droplets forming splats which had solidified upon impact on the substrate surface. The next droplets causing impact on already solidified splats were visible throughout the surface (Figure 1(e)).

$R_{a}$ and $R_{z}$ surface roughness values of the groups were found between the range of $0.05-5.77 \mu \mathrm{m}$ and $1.32-38.97 \mu \mathrm{m}$, respectively, where TPS coated surfaces had the highest 


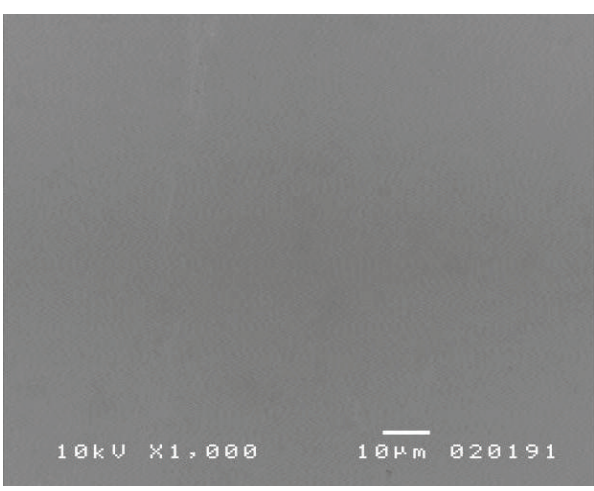

(a)

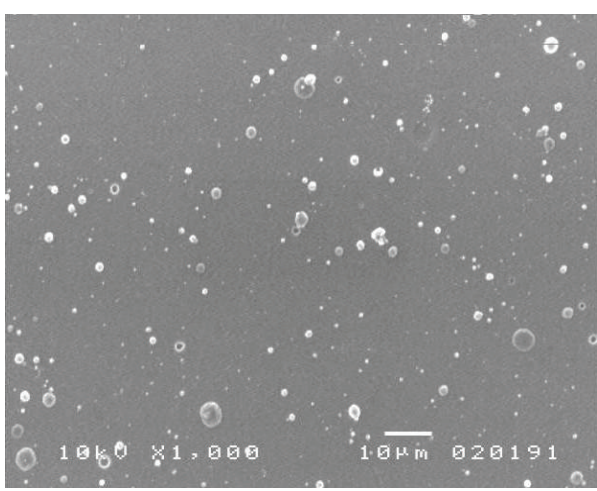

(c)

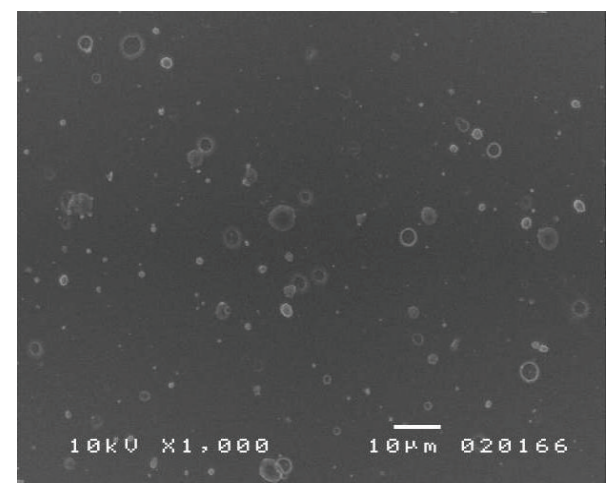

(b)

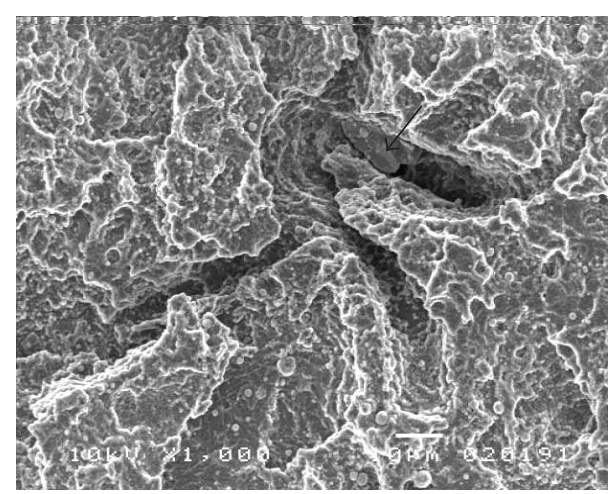

(d)

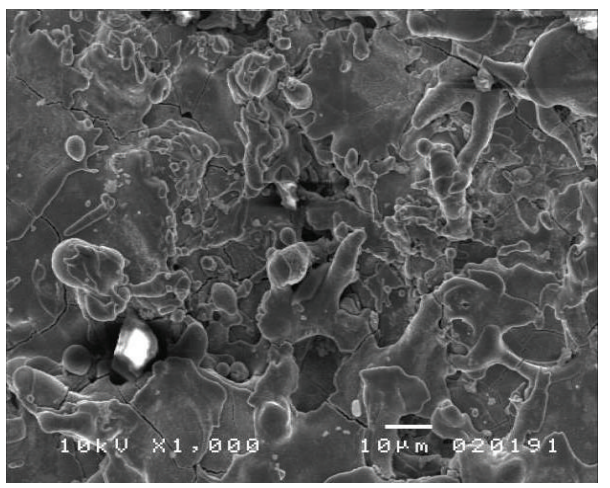

(e)

Figure 1: SEM images of the (a) Group P: few scratching marks without orientation, (b) Group TiN: droplets 0.5-3 $\mu \mathrm{m}$ in diameter, (c) Group C: droplets $0.5-3 \mu \mathrm{m}$ in diameter, and (d) Group SC: droplets $0.5-3 \mu \mathrm{m}$ in diameter residing within the microtopography of the sandblasted surfaces. $\mathrm{Al}_{2} \mathrm{O}_{3}$ particles (arrow) were also coated with the $\mathrm{TiO}_{2}$ coating; (e) Group TPS: droplets forming splats (original magnification $\times 1000$; all size bars $=10 \mu \mathrm{m})$.

$R_{a}$ and $R_{z}$ values among all the surfaces and polished surfaces had the lowest values (Table 1).

Figure 2 shows the XRD patterns of the prepared groups of surfaces. XRD of the Group P showed well-defined diffractions of Ti indicating the pure presence of this material. After coating with $\mathrm{TiO}_{2}$, reflections observed in the XRD pattern of Group $\mathrm{C}$ indicated the presence of $\mathrm{Ti}$ as the substrate material whereas anatase and rutile were indicated as welldeveloped coating substances. XRD patterns of the Group SC were rather similar to the Group C in terms of anatase and rutile peaks. However, Group SC consisted of additional
$\mathrm{TiO}$ peaks when compared to the Group C. $\mathrm{Al}_{2} \mathrm{O}_{3}$ peaks were not observed at the Group SC. Coating the polished surfaces with TiN revealed intense peak of the $\mathrm{Ti}_{2} \mathrm{~N}$, where minute amounts of $\mathrm{Ti}$ presence were observed at this group. This reflected that the TiN coating process had efficiently covered the underlying $\mathrm{Ti}$ substrate with $\mathrm{Ti}_{2} \mathrm{~N}$ at the Group TiN. The coating material of the Group TPS primarily consisted of TiN peaks and represented minor amounts of $\mathrm{Ti}_{3} \mathrm{O}$ peaks.

3.2. Cell Adhesion, Viability and Morphology Evaluation. The numbers of osteoblast cells at each group were increased by 


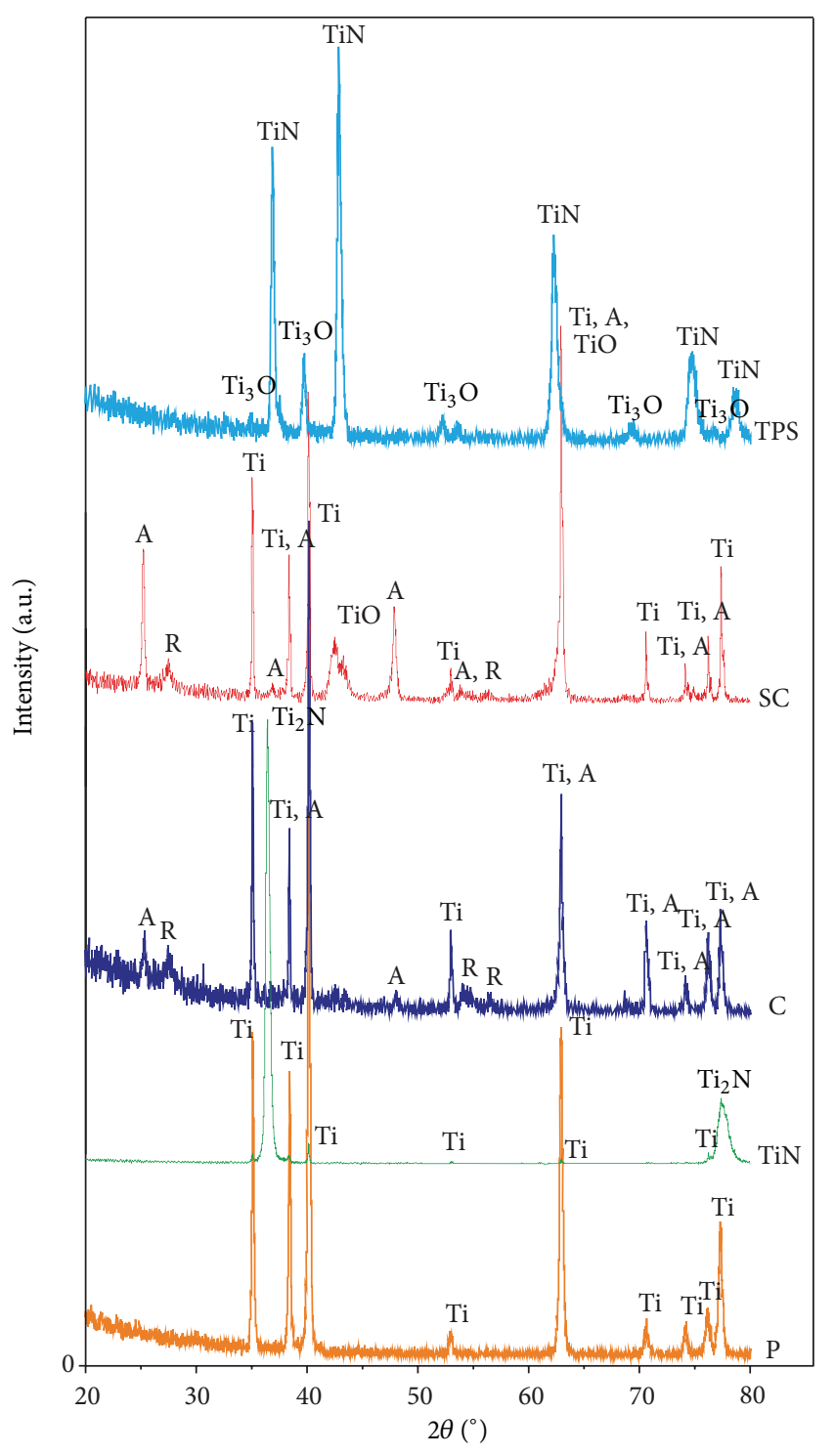

Figure 2: XRD patterns of (P) Group P, (TiN) Group TiN, (C) Group C, (SC) Group SC, and (TPS) Group TPS. Ti: titanium, A: anatase, and R: rutile.

the end of $24 \mathrm{~h}$. Highest mean total cell counts were found for the CG (42.41 \pm 7.10$)$ followed by the Group TPS (37.50 \pm 5.06). Lowest mean total cell counts were found as $25.66 \pm 5.22$ for the Group SC (Table 2).

$24 \mathrm{~h}$ cell viability data were expressed as the mean \pm SDs in Table 2. Cell viability at the Group SC was found significantly lower than it was at Groups P, TiN, C, and the CG.

SEM images had revealed that CRL-11372 cells displayed good adhesion on these five modified surfaces after $24 \mathrm{~h}$ from plating. Group SC (Figure 3(e)) showed sparsely oriented cells intimately attaching to their underlying valleys and hills with their cytoplasmic extensions while the other surfaces (Figures 3(a), 3(b), 3(c), 3(d), and 3(f)) showed confluent cell monolayers.
TABLE 2: Effects of the surfaces on CRL-11372 cell yield and viability after culturing for $24 \mathrm{~h}$.

\begin{tabular}{lcc}
\hline Group & Cell count $\left(\times 10^{4}\right.$ cells $\left./ \mathrm{mL}\right) \pm$ SD & Viability $(\%)$ \\
\hline P & $30.58 \pm 4.87^{*}$ & $91.17^{* *}$ \\
TiN & $29.50 \pm 3.33^{\dagger}$ & $89.42^{\dagger \dagger}$ \\
C & $36.37 \pm 4.47^{\ddagger}$ & $89.38^{\dagger \dagger}$ \\
SC & $25.66 \pm 5.22^{\S}$ & $82.77^{\ddagger \ddagger}$ \\
TPS & $37.50 \pm 5.06^{\|}$ & 86.57 \\
CG & $42.41 \pm 7.10^{9}$ & $91.08^{* *}$ \\
& $K W: 33.88$ & $K W: 17.34$ \\
& $P<0.0001$ & $P<0.004$ \\
\hline
\end{tabular}

${ }^{*}$ Significant difference compared with Groups C, SC, and TPS (significant at $95 \%$ ) and Group CG (significant at $99.9 \%$ ).

${ }^{\dagger}$ Significant difference compared with Groups C, TPS (significant at 95\%) and Group CG (significant at 99.9\%).

${ }^{\ddagger}$ Significant difference compared with Groups P, TiN, and CG (significant at 99.9\%) and Group SC (significant at 95\%).

${ }^{8}$ Significant difference compared with Groups C, TPS, and CG (significant at $99.9 \%$ ) and Group P (significant at 95\%).

"Significant difference compared with Groups P, TiN (significant at 95\%) and Group SC (significant at 99.9\%).

'Significant difference compared with Groups P, TiN, and SC (significant at 99.9\%) and Group C (significant at 95.0\%).

${ }^{* * *}$ Significant difference compared with Groups SC (significant at 99.9\%).

${ }^{\dagger \dagger}$ Significant difference compared with Groups SC (significant at 95.0\%).

${ }^{\ddagger}$ Significant difference compared with Groups TiN, C (significant at 95.0\%) and Groups P and CG, (significant at 99.9\%).

\section{Discussion}

PVD is one of the coating processes widely applied for $\mathrm{TiO}_{2}$ and TiN coatings at the biomedical field [12]. $\mathrm{TiO}_{2}$ coatings were produced by sol-gel [37], sputtering [31], chemical vapor deposition [38, 39], atomic layer deposition [40], plasma immersion ion implantation [41], and cathodic arc deposition techniques $[42,43]$. If the vaporization is primarily from the cathode surface by arc erosion, this system is called a cathodic arc source [34]. In our study, both $\mathrm{TiN}$ and $\mathrm{TiO}_{2}$ thin coatings are produced by cathodic arc deposition technique. This process allows film growth by the reaction between a substrate surface and an adjacent vapor. It supplies the coating material in the form of atoms, molecules, or ions that are generated from a target and transports them to the substrate surface, on which condensation and reaction with atoms of the surface lattice take place [44]. PVD has the advantage over other existing coating methods of being a reproducible process for depositing thin, stable, durable, and uniform coatings effectively masking the underlying surface chemistry without altering the surface topography [45].

Cell adhesion to the implant surfaces represents the initial interaction, and it is influenced by the surface chemical and topographical characteristics. In vitro studies conducted with various cell lines had stated TiN coated surfaces as biocompatible. MG63 human osteoblast-like cell lines were found to attach with high affinity to the sample surfaces in the order of hydroxyfluoride coated, TiN coated, smooth Ti, diamondlike carbon coated, SLA (sandblasted large grit and acid etched) treated, and hydroxyapatite thin coated surfaces [46]. 


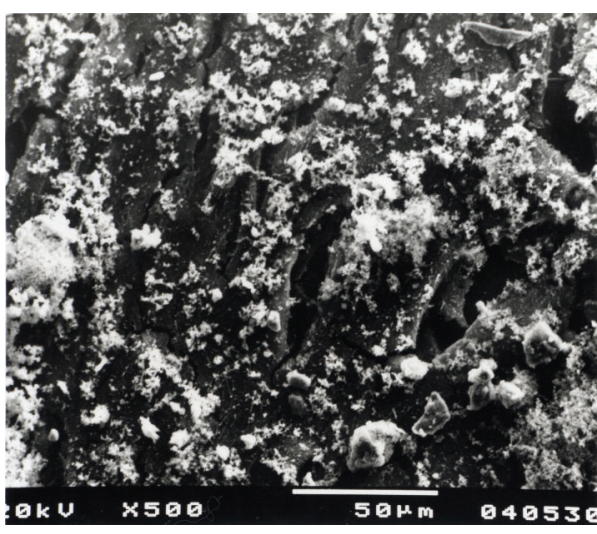

(a)

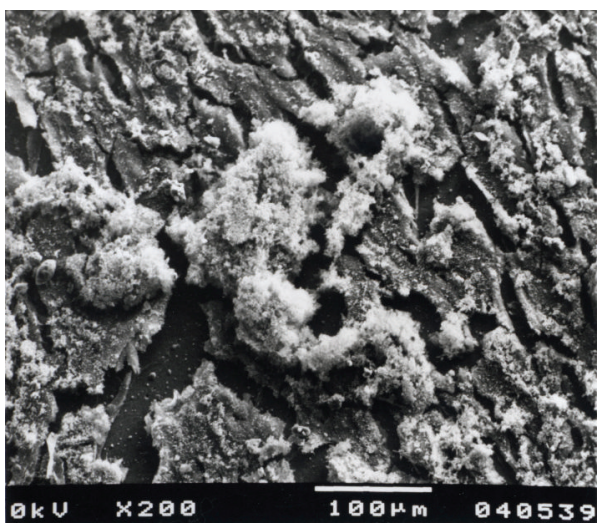

(c)

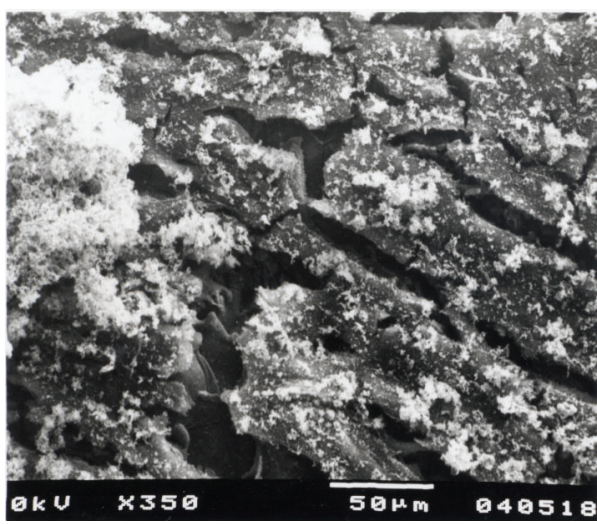

(e)

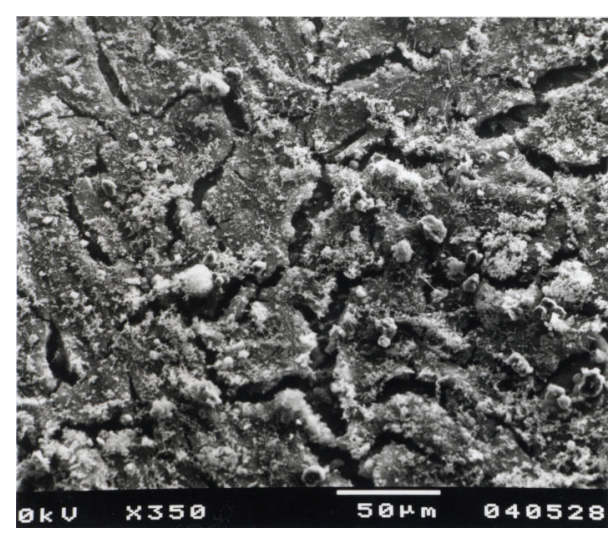

(b)

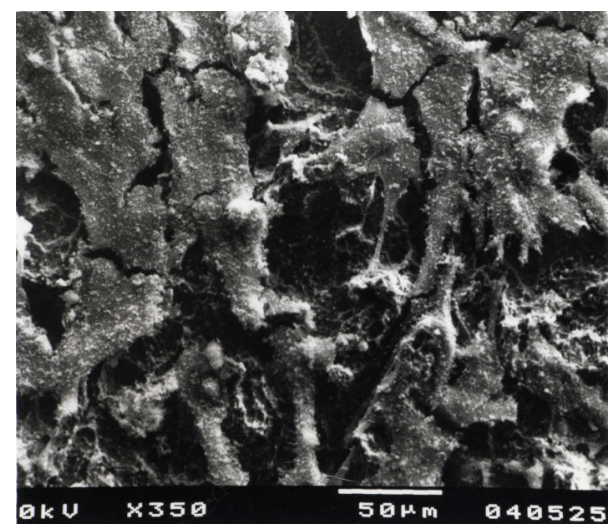

(d)

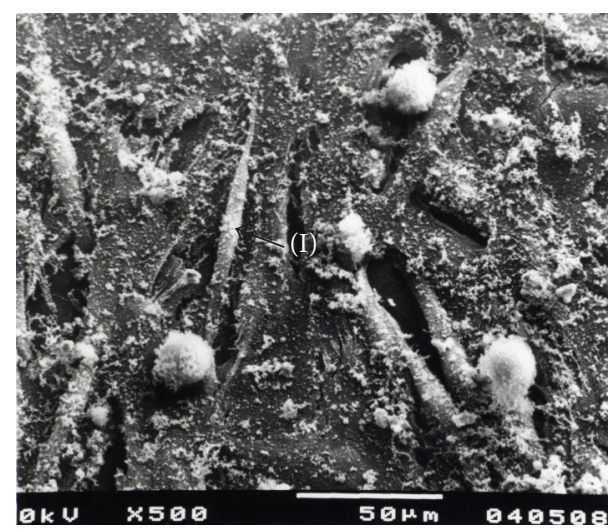

(f)

FIGURE 3: SEM images showing the morphology of CRL-11372 cells cultured for $24 \mathrm{~h}$ on (a) Group P: confluent monolayer of CRL-11372 cells (original magnification $\times 500$, bar $=50 \mu \mathrm{m})$, (b) Group TiN: confluent monolayer of CRL-11372 cells (original magnification $\times 350$, bar $=$ $50 \mu \mathrm{m}$ ), (c) Group C: confluent monolayer of CRL-11372 cells (original magnification $\times 200$, bar $=100 \mu \mathrm{m}$ ), and (d) Group SC: merely attached CRL-11372 cells. These cells bridged the valleys of the surface topography (original magnification $\times 350$, bar $=50 \mu \mathrm{m}$ ); (e) Group TPS: confluent monolayer of CRL-11372 cells (original magnification $\times 350$, bar $=50 \mu \mathrm{m}$ ), (f) CG cells displaying fusiform shapes of interphase (I) (arrow) stages of their cell cycles (original magnification $\times 500$, bar $=50 \mu \mathrm{m}$ ).

An in vitro study with mouse fibroblasts had revealed that MTT activities and total protein contents were significantly increased on TiN coated polished Ti surfaces compared to the thermally oxidized and laser radiation structured surfaces [47]. In another study, glass sheets coated with $\mathrm{Ti}$ and $\mathrm{TiN}$ presented the highest number of focal adhesion contacts (FACs) of human gingival fibroblasts as a proof of good adhesion [48]. Clem et al. [49] applied TiN coating onto Ti alloys by Microwave Plasma Chemical Vapor Deposition and investigated the biocompatibility of these newly formed TiN surfaces using different cell lines. According to the results of Manso-Silvan et al. [50], TiN coatings had displayed improved surface properties with respect to the traditional TiAlV alloys, acting as functional diffusion barriers avoiding 
negative effects of $\mathrm{Al}$ and $\mathrm{V}$ ions, and higher numbers of hMSCs were observed to have adhered onto these surfaces.

In our study, coatings at the Groups $\mathrm{TiN}$ and $\mathrm{C}$ were composed of different crystalline structures as $\mathrm{Ti}_{2} \mathrm{~N}$ and $\mathrm{TiO}_{2}$ (anatase and rutile), respectively (Figure 2). They both presented droplets $0.5-3 \mu \mathrm{m}$ in diameter yielding in similar surface profiles in terms of their $R_{a}$ and $R_{z}$ values (Table 1, Figures 1(b) and 1(c)). They had statistically similar percentage of cell viabilities compared with the CG approving their biocompatibility for CRL 11372 cells (Table 2). Mean total cell counts for the $\mathrm{TiO}_{2}$ coatings were found significantly higher from $\mathrm{Ti}_{2} \mathrm{~N}$ coatings at the end of $24 \mathrm{~h}$ (Table 2). $\mathrm{TiO}_{2}$ coated surfaces displayed significantly higher mean total $R_{a}$ and $R_{z}$ values and mean total cell counts compared to the polished surfaces at the end of 24 hours whereas TiN coated surfaces showed similar values with the polished surfaces. At these three groups, CRL 11372 cells adhered with high affinity to the underlying surfaces exhibiting confluent monolayers of cells (Figures 3(a), 3(b), and 3(c)). By comparing the surface of the titanium nitride coated substrates with that of the $\mathrm{TiO}_{2}$ coatings, biocompatibility is more pronounced in the latter case. Unlike, in the study of Ballo et al. [33], $\mathrm{TiO}_{2}$ coated implants did not alter the topographic values of the original machined implants. Scarano et al. [8] showed in their in vivo study that TiN coating had not changed the original texture of the machined, sandblasted, and TPS coated surfaces. Their results suggested that TiN might be a good coating for dental implants, independent of the type of the underlying surface topography used. In agreement to these findings Annunziata et al. [12] showed that TiN coating at the sandblasted surfaces showed comparable surface roughness values with respect to the uncoated sandblasted surfaces without modifying the topographical characteristics of these two surfaces. In our study, $\mathrm{Ti}_{2} \mathrm{~N}$ and $\mathrm{TiO}_{2}$ coatings changed the crystalline structures of the surfaces presenting similar surface roughness values. Sugita et al. [9] have applied $\mathrm{TiO}_{2}$ coatings using a slowrate sputter deposition of molten $\mathrm{TiO}_{2}$ nanoparticles to increase the surface oxygen components without altering the existing microtopography. These surfaces have been found to increase attachment, spreading behavior, proliferation, and differentiation of osteoblasts.

Group TPS had the roughest surface amongst all the groups in terms of their $R_{z}$ and $R_{a}$ values (Table 1). Group TPS and Group C surfaces had significantly different $R_{a}$ and $R_{z}$ values (Table 1). Group TPS had a structure of layering of splats on its surface and these were observed qualitatively different from the smaller sized surface droplets of the Group C (Figures 1(c) and 1(e)). Group TPS's surface crystalline structure was found to be composed of $\mathrm{TiN}$ and $\mathrm{Ti}_{3} \mathrm{O}$. These surfaces showed similar mean total cell counts to the $\mathrm{TiO}_{2}$ coated surfaces at the end of $24 \mathrm{~h}$ (Table 2). CRL-11372 cells formed a confluent monolayer on the $\mathrm{TiO}_{2}$ coated surfaces as well as on the TPS coated surfaces (Figures 3(c) and 3(e)). Controversially, TiN coated surfaces showed significantly lower mean total cell counts (Table 2) than the TPS coated surfaces. $\mathrm{TiO}_{2}$ and $\mathrm{Ti}_{3} \mathrm{O}$ oxides may have the possibility of giving rise to the biocompatibility of these surfaces rather than the $\mathrm{Ti}_{2} \mathrm{~N}$ and $\mathrm{TiN}$ content of their crystalline structures.
Group SC had $\mathrm{TiO}_{2}$, and Group TPS had TiN as well as $\mathrm{Ti}_{3} \mathrm{O}$ as their surface crystalline structures according to their XRD patterns (Figure 2). Group SC had the lowest mean total cell counts and cell viability amongst all groups at the end of $24 \mathrm{~h}$, although this group had the second rough surface coming after the Group TPS which contrarily showed the highest mean total cell counts and cell viability (Tables 1 and 2). Rough surface of the Group SC did not improve the mean total cell counts and viability as expected. These findings are also supported by the SEM images of sparsely grown CRL-11372 cells on these surfaces (Figures 3(d), 3(e), and $3(\mathrm{f}))$. So roughness had no effect on the mean total cell counts and viabilities of the cells. This can be associated to the Group SC's surface coating's crystalline structure and its effect on CRL-11372 cells. TiO coated $\mathrm{Al}_{2} \mathrm{O}_{3}$ particles that were impacted to the surface of the Group SC did not have a negative effect at the adhesion of the CRL 11372 cells. So, rather than the different surface roughness values, $\mathrm{TiO}$ content of the crystalline structure of this surface might have affected the biocompatibility of the surfaces in Group SC in a negative direction.

\section{Conclusions}

Based on our results we suggest that, under controlled conditions of PVD coating process, titanium oxide and titanium nitride coatings can be produced with or without altering the roughness features of the polished surfaces. It is noteworthy that, for every surface treatment, crystalline structures ultimately lead to different cellular adhesion responses among the groups regardless of the surface roughness values.

In the opinion of the authors, to correctly interpret these findings, further studies are needed including the determination of cellular molecules during the cell culture experiments with time intervals more than $24 \mathrm{~h}$ in order to draw more detailed conclusions for longer terms of osteoblast cells' responses.

\section{Acknowledgments}

The authors thank the Dentsply Friadent (Mannheim, Germany) for providing the P discs and TPS coated discs. In this study, preparation and characterization of the commercially pure titanium metal surfaces were supported by The Research Support Unit of Istanbul University as the project no. $1749 / 21122001$. The polished (P) discs in this study were supplied by Dentsply Friadent (Mannheim, Germany), and this firm has no involvement in the study design including the collection, analysis, interpretation of the data, writing the report, and the decision of submitting the report for publication. The authors of the paper do not have a direct financial relation with the software SPSS Inc., Chicago, USA.

\section{References}

[1] A. Bruinink and E. Wintermantel, "Grooves affect primary bone marrow but not osteoblastic MC3T3-E1 cell cultures," Biomaterials, vol. 22, no. 18, pp. 2465-2473, 2001. 
[2] H. J. Rønold and J. E. Ellingsen, "Effect of micro-roughness produced by $\mathrm{TiO}_{2}$ blasting-tensile testing of bone attachment by using coin-shaped implants," Biomaterials, vol. 23, no. 21, pp. 4211-4219, 2002.

[3] R. Lange, F. Lüthen, U. Beck, J. Rychly, A. Baumann, and B. Nebe, "Cell-extracellular matrix interaction and physicochemical characteristics of titanium surfaces depend on the roughness of the material," Biomolecular Engineering, vol. 19, no. 2-6, pp. 255-261, 2002.

[4] K. Anselme, "Review: osteoblast adhesion on biomaterials," Biomaterials, vol. 21, no. 7, pp. 667-681, 2000.

[5] K. Anselme and M. Bigerelle, "Topography effects of pure titanium substrates on human osteoblast long-term adhesion," Acta Biomaterialia, vol. 1, no. 2, pp. 211-222, 2005.

[6] L. F. Cooper, T. Masuda, S. W. Whitson, P. Yliheikkilä, and D. A. Felton, "Formation of mineralizing osteoblast cultures on machined, titanium oxide grit-blasted, and plasma-sprayed titanium surfaces," International Journal of Oral and Maxillofacial Implants, vol. 14, no. 1, pp. 37-47, 1999.

[7] E. Eisenbarth, P. Linez, V. Biehl, D. Velten, J. Breme, and H. F. Hildebrand, "Cell orientation and cytoskeleton organisation on ground titanium surfaces," Biomolecular Engineering, vol. 19, no. 2-6, pp. 233-237, 2002.

[8] A. Scarano, M. Piattelli, G. Vrespa, G. Petrone, G. Iezzi, and A. Piattelli, "Bone healing around titanium and titanium nitridecoated dental implants with three surfaces: an experimental study in rats," Clinical Implant Dentistry and Related Research, vol. 5, no. 2, pp. 103-111, 2003.

[9] Y. Sugita, K. Ishizaki, F. Iwasa et al., "Effects of pico-tonanometer-thin $\mathrm{TiO}_{2}$ coating on the biological properties of microroughened titanium," Biomaterials, vol. 32, no. 33, pp. 8374-8384, 2011.

[10] J. Harle, H. Kim, N. Mordan, J. C. Knowles, and V. Salih, "Initial responses of human osteoblasts to sol-gel modified titanium with hydroxyapatite and titania composition," Acta Biomaterialia, vol. 2, no. 5, pp. 547-556, 2006.

[11] S. Rossi, T. Tirri, H. Paldan, H. Kuntsi-Vaattovaara, R. Tulamo, and T. Närhi, "Peri-implant tissue response to $\mathrm{TiO}_{2}$ surface modified implants," Clinical Oral Implants Research, vol. 19, no. 4, pp. 348-355, 2008.

[12] M. Annunziata, L. Guida, L. Perillo, R. Aversa, I. Passaro, and A. Oliva, "Biological response of human bone marrow stromal cells to sandblasted titanium nitride-coated implant surfaces," Journal of Materials Science, vol. 19, no. 12, pp. 3585-3591, 2008.

[13] J. A. Hendry and R. M. Pilliar, "The fretting corrosion resistance of PVD surface-modified orthopedic implant alloys," Journal of Biomedical Materials Research, vol. 58, no. 2, pp. 156-166, 2001.

[14] J. Bolton and X. Hu, "In vitro corrosion testing of PVD coatings applied to a surgical grade Co-Cr-Mo alloy," Journal of Materials Science, vol. 13, no. 6, pp. 567-574, 2002.

[15] J. Zhao, X. M. Cai, H. Q. Tang, T. Liu, H. Q. Gu, and R. Z. Cui, "Bactericidal and biocompatible properties of TiN/Ag multilayered films by ion beam assisted deposition," Journal of Materials Science, vol. 20, supplement 1, pp. S101-S105, 2009.

[16] I. Dion, C. Baquey, B. Candelon, and J. R. Monties, "Hemocompatibility of titanium nitride," International Journal of Artificial Organs, vol. 15, no. 10, pp. 617-621, 1992.

[17] I. Dion, X. Roques, N. More et al., "Ex vivo leucocyte adhesion and protein adsorption on TiN," Biomaterials, vol. 14, no. 9, pp. 712-719, 1993.
[18] I. Dion, F. Rouais, L. Trut, C. Baquey, J. R. Monties, and P. Havlik, "TiN coating: surface characterization and haemocompatibility," Biomaterials, vol. 14, no. 3, pp. 169-176, 1993.

[19] A. Wisbey, P. J. Gregson, and M. Tuke, "Application of PVD TiN coating to Co-Cr-Mo based surgical implants," Biomaterials, vol. 8, no. 6, pp. 477-480, 1987.

[20] P. R. Mezger and N. H. J. Creugers, “Titanium nitride coatings in clinical dentistry," Journal of Dentistry, vol. 20, no. 6, pp. 342344, 1992.

[21] C. D. Peterson, B. M. Hillberry, and D. A. Heck, "Component wear of total knee prostheses using Ti-6Al-4V, titanium nitride coated Ti- $6 \mathrm{Al}-4 \mathrm{~V}$, and cobalt-chromium-molybdenum femoral components," Journal of Biomedical Materials Research, vol. 22, no. 10, pp. 887-903, 1988.

[22] M. I. Jones, I. R. McColl, D. M. Grant, K. G. Parker, and T. L. Parker, "Protein adsorption and platelet attachment and activation, on TiN, TiC, and DLC coatings on titanium for cardiovascular applications," Journal of Biomedical Materials Research, vol. 52, no. 2, pp. 413-421, 2000.

[23] E. Y. Gutmanas and I. Gotman, "PIRAC Ti nitride coated Ti-6AI-4V head against UHMWPE acetabular cup-hip wear simulator study," Journal of Materials Science, vol. 15, no. 4, pp. 327-330, 2004.

[24] S. Areva, V. Aäritalo, S. Tuusa, M. Jokinen, M. Lindén, and T. Peltola, "Sol-Gel-derived $\mathrm{TiO}_{2}-\mathrm{SiO}_{2}$ implant coatings for direct tissue attachment, part II: evaluation of cell response," Journal of Materials Science, vol. 18, no. 8, pp. 1633-1642, 2007.

[25] H. Kim, H. Kim, V. Salih, and J. C. Knowles, "Hydroxyapatite and titania sol-gel composite coatings on titanium for hard tissue implants; mechanical and in vitro biological performance," Journal of Biomedical Materials Research B, vol. 72, no. 1, pp. 1-8, 2005.

[26] S. Lee, H. Kim, E. Lee, L. Li, and H. Kim, "Hydroxyapatite$\mathrm{TiO}_{2}$ hybrid coating on Ti implants," Journal of Biomaterials Applications, vol. 20, no. 3, pp. 195-208, 2006.

[27] S. Areva, H. Paldan, T. Peltola, T. Närhi, M. Jokinen, and M. Lindén, "Use of sol-gel-derived titania coating for direct soft tissue attachment," Journal of Biomedical Materials Research A, vol. 70, no. 2, pp. 169-178, 2004.

[28] V. V. Meretoja, S. Rossi, T. Peltola, L. J. Pelliniemi, and T. O. Närhi, "Adhesion and proliferation of human fibroblasts on solgel coated titania," Journal of Biomedical Materials Research A, vol. 95, no. 1, pp. 269-275, 2010.

[29] A. Wennerberg, V. Fröjd, M. Olsson et al., "Nanoporous $\mathrm{TiO}_{2}$ thin film on titanium oral implants for enhanced human soft tissue adhesion: a light and electron microscopy study," Clinical Implant Dentistry and Related Research, vol. 13, no. 3, pp. 184196, 2011.

[30] B. Größner-Schreiber, M. Griepentrog, I. Haustein et al., "Plaque formation on surface modified dental implants-an in vitro study," Clinical Oral Implants Research, vol. 12, no. 6, pp. 543-551, 2001.

[31] K. Shieh, M. Li, Y. Lee, S. Sheu, Y. Liu, and Y. Wang, "Antibacterial performance of photocatalyst thin film fabricated by defection effect in visible light," Nanomedicine, vol. 2, no. 2, pp. 121-126, 2006.

[32] M. Chatzinikolaidou, T. K. Lichtinger, R. T. Müller, and H. P. Jennissen, "Peri-implant reactivity and osteoinductive potential of immobilized rhBMP-2 on titanium carriers," Acta Biomaterialia, vol. 6, no. 11, pp. 4405-4421, 2010.

[33] A. M. Ballo, D. Bjöörn, M. Astrand, A. Palmquist, J. Lausmaa, and $\mathrm{P}$. Thomsen, "Bone response to physical vapour deposited 
titanium dioxide coatings on titanium implants," Clinical Oral Implants Research, vol. 15, 2012.

[34] D. M. Mattox, Handbook of Physical Vapor Deposition (PVD) Processing, Noyes, Park Ridge, NJ, USA, 1998.

[35] X. Liu, P. K. Chu, and C. Ding, "Surface modification of titanium, titanium alloys, and related materials for biomedical applications," Materials Science and Engineering R, vol. 47, no. 3-4, pp. 49-121, 2004.

[36] V. Viswanathan, T. Laha, K. Balani, A. Agarwal, and S. Seal, "Challenges and advances in nanocomposite processing techniques," Materials Science and Engineering R, vol. 54, no. 5-6, pp. 121-285, 2006.

[37] J. Yu, X. Zhao, and Q. Zhao, "Photocatalytic activity of nanometer $\mathrm{TiO}_{2}$ thin films prepared by the sol-gel method," Materials Chemistry and Physics, vol. 69, no. 1-3, pp. 25-29, 2001.

[38] D. Byun, Y. Jin, B. Kim, J. Kee Lee, and D. Park, "Photocatalytic $\mathrm{TiO}_{2}$ deposition by chemical vapor deposition," Journal of Hazardous Materials, vol. 73, no. 2, pp. 199-206, 2000.

[39] K. Wang, Y. Hsieh, P. Chao, and C. Cgang, “The photocatalytic degradation of trichloroethane by chemical vapor deposition method prepared titanium dioxide catalyst," Journal of Hazardous Materials, vol. 95, no. 1-2, pp. 161-174, 2002.

[40] M. Kemell, V. Pore, M. Ritala, M. Leskelä, and M. Lindén, "Atomic layer deposition in nanometer-level replication of cellulosic substances and preparation of photocatalytic $\mathrm{TiO}_{2} /$ cellulose composites," Journal of the American Chemical Society, vol. 127, no. 41, pp. 14178-14179, 2005.

[41] S. Mändl, R. Sader, G. Thorwarth et al., "Investigation on plasma immersion ion implantation treated medical implants," Biomolecular Engineering, vol. 19, no. 2-6, pp. 129-132, 2002.

[42] A. Bendavid, P. J. Martin, and H. Takikawa, "Deposition and modification of titanium dioxide thin films by filtered arc deposition," Thin Solid Films, vol. 360, no. 1-2, pp. 241-249, 2000.

[43] H. Yumoto, S. Matsudo, and K. Akashi, "Photocatalytic decomposition of $\mathrm{NO}_{2}$ on $\mathrm{TiO}_{2}$ films prepared by arc ion plating," Vacuum, vol. 65, no. 3-4, pp. 509-514, 2002.

[44] D. M. Brunette, P. Tengvall, M. Textor, and P. Thomsen, Titanium in Medicine, Springer, New York, NY, USA, 2001.

[45] S. A. Hacking, M. Zuraw, E. J. Harvey, M. Tanzer, J. J. Krygier, and J. D. Bobyn, "A physical vapor deposition method for controlled evaluation of biological response to biomaterial chemistry and topography," Journal of Biomedical Materials Research A, vol. 82, no. 1, pp. 179-187, 2007.

[46] C.-S. Kim, S.-H. Sohn, S.-K. Jeon, K.-N. Kim, J.-J. Ryu, and M.-K. Kim, "Effect of various implant coatings on biological responses in MG63 using cDNA microarray," Journal of Oral Rehabilitation, vol. 33, no. 5, pp. 368-379, 2006.

[47] B. Groessner-Schreiber, A. Neubert, W. Müller, M. Hopp, M. Griepentrog, and K. Lange, "Fibroblast growth on surfacemodified dental implants: an in vitro study," Journal of Biomedical Materials Research A, vol. 64, no. 4, pp. 591-599, 2003.

[48] B. Größner-Schreiber, M. Herzog, J. Hedderich, A. Dück, M. Hannig, and M. Griepentrog, "Focal adhesion contact formation by fibroblasts cultured on surface-modified dental implants: an in vitro study," Clinical Oral Implants Research, vol. 17, no. 6, pp. 736-745, 2006.

[49] W. C. Clem, V. V. Konovalov, S. Chowdhury, Y. K. Vohra, S. A. Catledge, and S. L. Bellis, "Mesenchymal stem cell adhesion and spreading on microwave plasma-nitrided titanium alloy," Journal of Biomedical Materials Research A, vol. 76, no. 2, pp. 279287, 2006.
[50] M. Manso-Silvan, J. M. Martínez-Duart, S. Ogueta, P. GarcíaRuiz, and J. Pérez-Rigueiro, "Development of human mesenchymal stem cells on DC sputtered titanium nitride thin films," Journal of Materials Science, vol. 13, no. 3, pp. 289-293, 2002. 

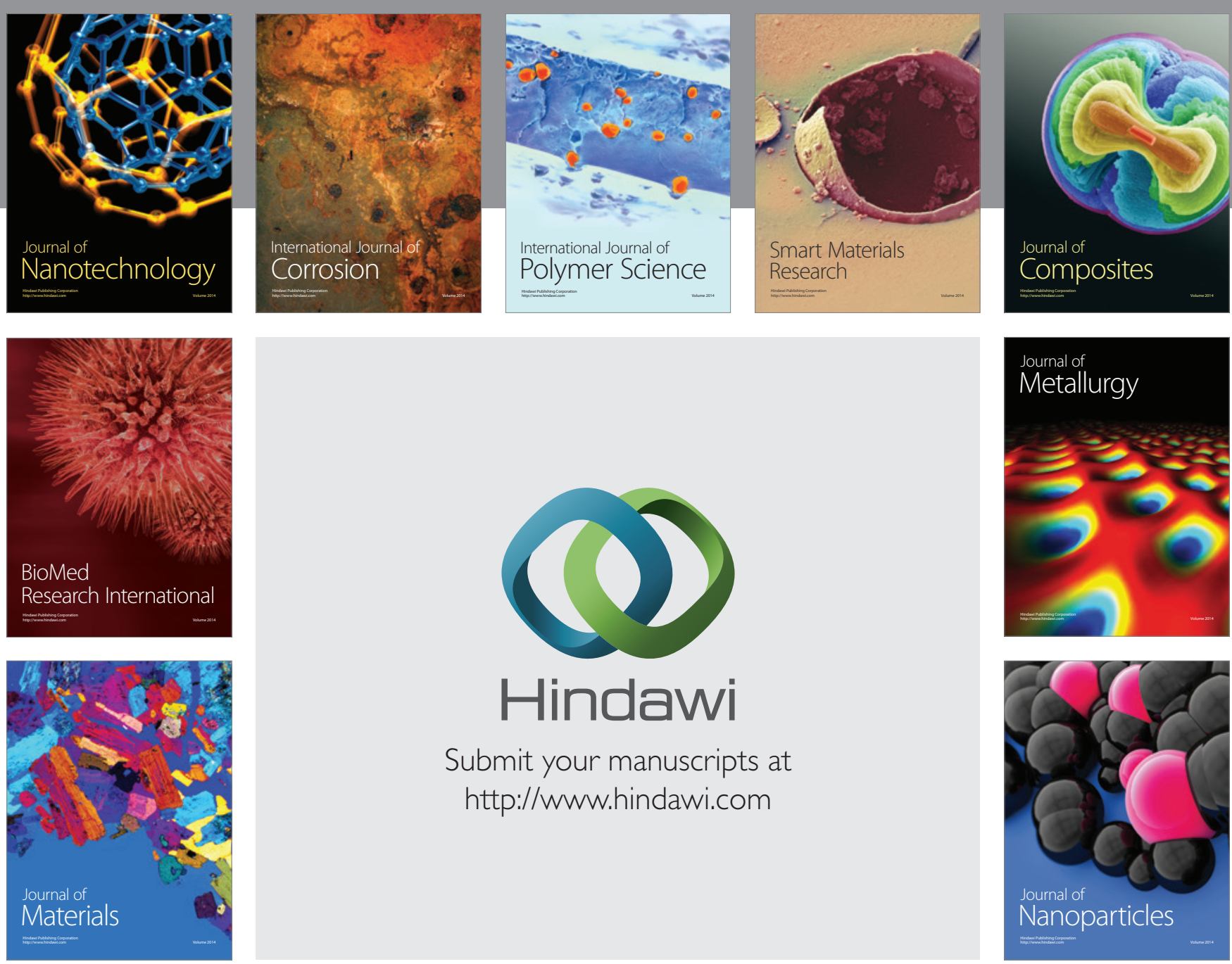

Submit your manuscripts at http://www.hindawi.com
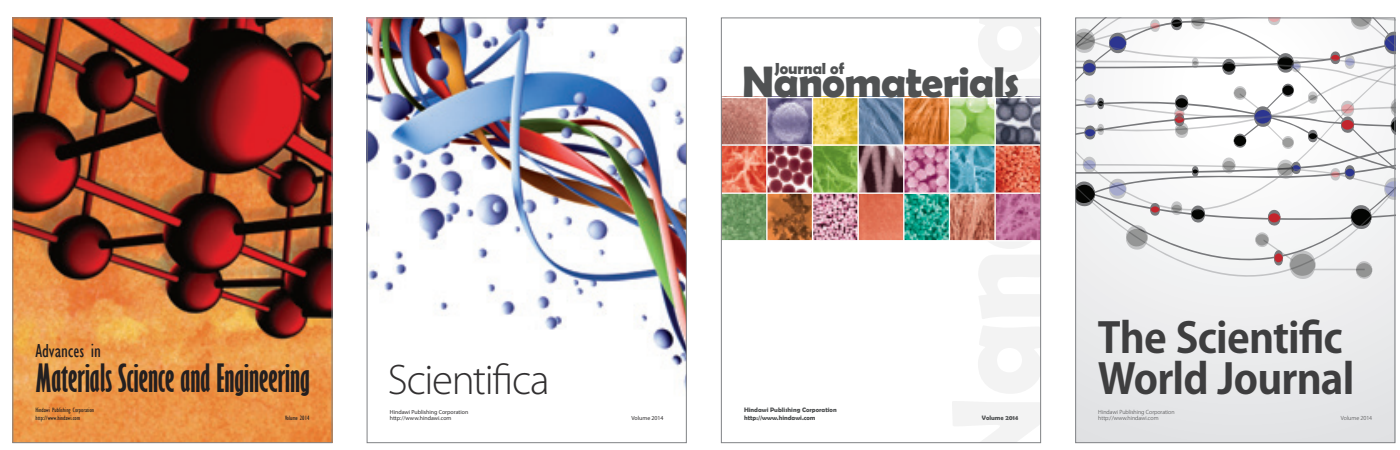

\section{The Scientific World Journal}
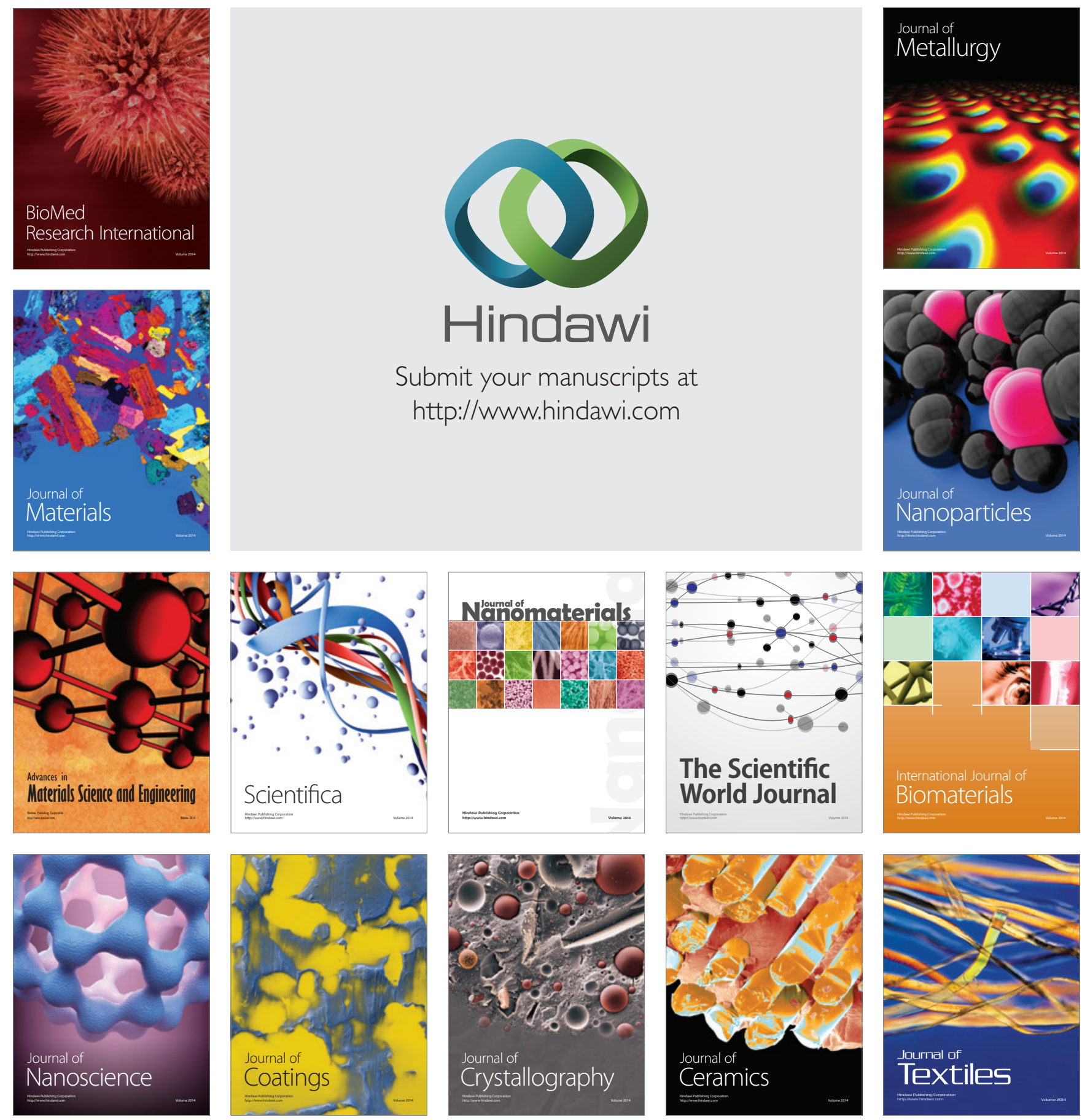